\section{Francesco}

\section{Piccolomini's}

\section{Platonism and}

\section{Nicolas of Cusa}

in the "Peripatetic Exercise" of

\section{Johannes Jessenius}

\section{On Divine and}

\section{Human Philosophy}

ABSTRACT

The aim of the article is to analyse Johannes Jessenius' book (1565-1621) De divina humanaque philosophia (Padua 1591). The book is titled progymnasma peripateticum and was a product of Jessenius' philosophical studies in Padua. Although it was earlier characterized as a disputation written in a traditional AristotelianScholastic way, the analysis shows that Jessenius followed up on Platonising the Aristotelianism of his teacher Francesco Piccolomini and incorporated certain Platonic elements into an Aristotelian pattern. In addition, the book contains passages that appear to be inspired by the works of Nicolas of Cusa at least with respect to philosophical terminology. Jessenius' Padua disputation thus confirms the dissemination of Cusanus' philosophy in $16^{\text {th }}$ century Italy.*

\title{
TOMÁŠ NEJESCHLEBA
}

Palacky University Olomouc, Department of Philosophy, Křižlkovského 12, Olomouc Czech Republic tomas.nejeschleba@upol.cz https://doi.org/10.5507/aither.2020.012

The study is a result of the research funded by the Czech Science Foundation as the project GA ČR 19-07439S "Philosophy of Renaissance Medicine in the Czech Lands (Jessenius - Hájek - Khunrath - Paracelsus). New Approaches and Contexts." The article follows my monograph Nejeschleba 2008 and the study Nejeschleba 2019. 


\section{INTRODUCTION}

Johannes Jessenius, a Physician, anatomist, politician and philosopher, (Wroclaw 1566 - 1621 Prague) is renowned as the intellectual who brought late Renaissance Northern Italian medicine and philosophy to Central Europe. His studies in Padua played a crucial role in his later activities in Wittenberg, Vienna, and Prague. Most of his works refer explicitly or implicitly to the education he acquired in Padua where he enrolled to study philosophy and medicine in 1588 and stayed there until the end of 1591. In medicine, Jessenius proudly mentioned Girolamo Fabrici ab Aquapendente as his teacher. In philosophy, although Jessenius was influenced by more authors, he considered himself a pupil of Francesco Piccolomini. ${ }^{1}$
A direct result of Jessenius' philosophical studies in Padua was A Peripatetic Exercise on Divine and Human Philosophy (De divina humanaque philosophia progymnasma peripateticum). The book echoes both the philosophical education that Jessenius obtained in Padua and Jessenius' early philosophical thought. ${ }^{2}$

Jessenius explicitly refers to Piccolomini in his edition of Savonarola, see Savonarola 1596, p. 768. Francesco Piccolomini, together with other Padua Professors, namely Girolamo Fabrici ab Aquapendente, Aemilo Campolongo, Bernardino Petrella, and Cesare Cremonini, confirmed later in a specific document that Jessenius finished his studies in Padua. The transcript of "Jessenius' diploma" see in Pick 1926, pp. 274-75.

Jessenius' philosophy was later developing by means of the influence of Francesco Patrizi's book Nova de universis philosophia in particular. See Nejeschleba 2014. 
This is the only book that Jessenius published in Italy, specifically in Venice. ${ }^{3}$ Jessenius writes that it was publicly disputed at Padua university, but the publication of the book was in fact not meant for learned Italian readers. Its purpose was, rather, to find a patron in the Transalpine region and a good position in the Roman empire. Jessenius reached for the stars and dedicated the book to the emperor Rudolph II. ${ }^{4}$ The dedicatory letter is dated on July 24 , 1591, two weeks before Jessenius' public disputation on medicine which was held on August 8, 1591 in the Franciscan church in Padua. ${ }^{5}$

In my paper, I will analyse the content of Jessenius' book On Divine and Human Philosophy. Although the work was earlier labelled as a traditional Aristotelian-Scholastic work, ${ }^{6}$ probably with respect to its title "Peripatetic Exercise", I will show that it contains both Aristotelian and Platonic elements

3 Jessenius 1591a. Other two Jessenius' Italian prints do not have a character of books. Both were printed in Padua and are quite short. The first one is the elegy on a Czech noble man Zdeněk Vojtěch Popel of Lobkovic, the second one is a short medical disputation, see below.

4 Jessenius' dream to have a position at the court of the emperor Rudolph II has never fulfilled. Later in his career Jessenius worked as physician at the Vienna court of Rudolph's brother Matthias.

5 It was a medical disputation, see Jessenius 1591b. In addition, Jessenius at the same date allegedly held another disputation on philosophy, which he later published as Pro vindiciis contra tyrranos oratio in Frankfurt a. M. in 1614 and in Prague in 1620. To the modern Latin edition see Šolcová 2015 and Jesenský 2019.

6 As it was inaccurately maintained by Král 1923, p. 134 and Várossová 1987, p. 77. as it was characteristic of Francesco Piccolomini's philosophy. I will also discuss a possible influence of Nicolas of Cusa's philosophy on Jessenius' book since it seems at least to be using Cusanus' specific philosophical terminology.

\section{JESSENIUS AND PICCOLOMINI: PLATONISING ARISTOTELIANISM}

Jessenius' teacher Francesco Piccolomini (1523-1601) was in no way a pure Aristotelian thinker. ${ }^{7}$ Already his contemporaries characterize him as a philosopher "of Aristotle's soul and Plato's spirit." Due to this ambiguity, it seems to be difficult for modern historians to characterize his philosophy unequivocally. The extreme interpretations oscillate between labelling Piccolomini a Platonist ${ }^{9}$ or an Aristotelian, ${ }^{10}$ while most interpreters strive to delineate the relationship between the two philosophical streams in Piccolomini's thought while holding the two sides together. His philosophy is then viewed as "eclectic Aristotelianism" combining Aristotelianism with nonAristotelian elements, ${ }^{11}$ or as mediating

7 To Piccolomini's biography and different interpretations of his thought see Lines $2015 b$.

8 It is a quotation from the speech over Piccolomini's grave, see Baldini 1980, p. 389.

9 Referring to Pietro Ragnisco's description of Piccolomini as "a Platonist in a mask of Aristotle", see Garin 2008, pp. 437-438.

10 See Spruit 1995, 238-240.

11 With respect to moral philosophy in particular, see Kraye 2002. Cf. Lines 2002, pp. 254-288; Lines 2015a. To eclectic Aristotelianism in the Renaissance see Schmitt 1983. 
between Aristotle and Neoplatonism, ${ }^{12}$ or even as an attempt at a concord between Plato and Aristotle. ${ }^{13}$

One can see the tendency to incorporate both Aristotelian and Platonic thoughts also in Jessenius' book. It is titled "a Peripatetic exercise" on one hand, i. e. Jessenius proclaims an Aristotelian way of dealing with the topic. On the other hand, Jessenius' friend Theodor Collado Biturix, who wrote a celebratory poem introducing Jessenius' book, praises Jessenius for having surpassed Aristotle. Biturix's poem, certainly, may be no more than rhetoric meant to attract potential readers or donators and need not be an accurate description of the content of the book. The book itself, however, really shows a familiarity with Francesco Piccolomini's Platonising of Aristotelianism and even a dependence on it.

Firstly, the topic of Jessenius' book is in accord with one of Piccolomini's crucial philosophical themes, i.e. the issue of the hierarchy of disciplines. The book deals with the definition of the relationship between divine philosophy (as metaphysics was traditionally referred to) and human philosophy (meaning natural philosophy). In the introduction Jessenius attempted to justify the fact that they were referred to as two different kinds of knowledge (duo scientiarum genera). This distinction, however, did not reflect different modes of thinking, but the two different methods of processing researched material gathered from experience. Things can be contemplated

12 See Kessler 2007, p. 528. Cf. Claessens 2012; Claessens 2014.

13 See Plastina 2002. in terms of what they are, which is the task of physics, defined by Jessenius as a science whose subject is nature. This natural philosophy thus deals with things in terms of their essences, which is basically the traditional Aristotelian concept of natural philosophy.

Jessenius' concept of metaphysics proves to be the key to interpreting his argument. He believed that metaphysics does not deal with the essences of things, but the differences between them, therefore it "orders" (ordinat) beings (i.e. puts them in order). ${ }^{14}$ The characteristics of order as the subject of metaphysics provided by Jessenius in the first paragraph of his treatise confirm that the Padua university graduate was truly close to Piccolomini, who believed that ordo reflects the ontological structure of reality. ${ }^{15}$

As it is well known, Piccolomini's emphasis on ordo is the key point of his disagreement with Jacopo Zabarella. It concerns the issue of the hierarchy of disciplines and the meaning of natural philosophy, logic, and of metaphysics in particular. In the polemics, Piccolomini attacked Zabarella's notion of order as nothing more than a procedure applied to interpret knowledge and his notion that order has a purely instrumental role, being used together with the method by which we achieve knowledge. Piccolomini, on contrary, believed

14 Rerum autem essentiam Physica (quae naturae rerum scientiam definitur) explicat; earum vero ordinem et differentias, communis philosophia (metaphysica dicta) edocet. Jessenius 1591a, c. 1, 1r.

15 Here, Piccolomini differs from Jacopo Zabarella with whom he polemized, see Jardine 1997. 
that order stands above the method: the order of knowledge is an imitation of the order of nature, which, in turn, reflects the divine order. It is here that a very distinct Platonic element emerged in his concept: the idea of the relationship between the pattern and the image and the ontological dependence of the image on the pattern. This Platonic exemplarism then fully reflects itself in Piccolomini's concept of the hierarchy of knowledge and in the dependence of the disciplines of cognition on superior disciplines situated higher in the hierarchy. In contrast to Zabarella, Piccolomini required that metaphysics provide the backbone to all other sciences and serve as a cornerstone for natural philosophy which, in turn, is the foundation of other special fields. The activities of a natural philosopher respecting the divine origin of order have to imitate the fixed ontological structure of the arrangement of nature.

It is necessary to place Jessenius' book dealing with the relationship between natural philosophy and metaphysics in the context of Piccolomini's view on the nature of order. The affiliation - or rather reliance - on Piccolomini's philosophy in Jessenius' theories becomes apparent in the paragraphs that followed in his book. When Jessenius refers to differences, he distinguishes between differences inherent to individual things (i.e. existing as a part of their essence and their substantial form) and the so-called common differences (differentiae communes). Physics employs differences through which individual things are defined. These may be called properties of individuals, species and genera. However, in order to obtain the overall picture of the real situation, we must look for common differences that is the differences on the common level. Inherent differences only reveal the specifics of one thing, yet do not disclose how it differs from another. These common differences should obviously refer to general concepts that reflect reality and that have metaphysical validity and are not merely mental signs marking individual beings. Through these general concepts, we obtain the picture of an ontological order within the framework of which individual beings are set. Jessenius continued saying that natural philosophy, is therefore also bound to metaphysics, not being able to do without it since metaphysics instructs us about the relations between individual beings, which would otherwise be conceived of as isolated units. ${ }^{16}$

Jessenius' statement clearly echoes Piccolomini's idea of the subordination of natural philosophy to metaphysics, which is highlighted in the following chapter dealing with the "true order of things". All things suggest that they are a part of an order in a tiered arrangement that is revealed when differences between the individual beings are compared. ${ }^{17}$ Each individual being represents the unity of its place which is its inherent difference, yet thus already referring to God who is the principle of this unity and in whose divinity the being participates and whom it resembles, since nothing dissimilar comes from God. God, Jessenius

16 Jessenius $1591 \mathrm{a}$, c. $2,1 \mathrm{v}$.
17 Jessenius $1591 \mathrm{a}$, c. $3,1 \mathrm{v}$. 
continues, is the first and foremost being, a being in itself, the second being is an angel, coming from God, and the third being is man. In the hierarchy, man and angel share a common difference through which they both are like God. Their other differences, however, are unalike, therefore they bear different names and differ from one another. ${ }^{18}$ At this point Jessenius, like Piccolomini, complements the Aristotelian structure of his treatise with distinct Platonic elements.

Let us move onto main differences between natural philosophy and metaphysics as perceived by Jessenius. Jessenius characterises "physics" as a science that deals with individual things, substances and accidents, however, disregarding their mutual relations and their arrangement within some order. Nevertheless, metaphysics has set a higher goal, as Jessenius himself puts it, to view individual things from the perspective of general principles. It will allow us to determine what is more and what is less perfect; what is substantial and what is accidental; what is earlier and what is later; what is subordinated and what is superior. Therefore, it is the "head of all sciences" and the discipline that determines their hierarchy. ${ }^{19}$ There are numerous natural philosophies, since a natural philosophy always speaks of individual items. Yet, metaphysics is specific in that it is able to grasp all things in a unity.

Jessenius further defined the relationship between physics and metaphysics

\footnotetext{
18 Jessenius 1591a, c. 3, 2r.

19 Jessenius 1591a, c. 6, 4r.
}

using the introductory chapter of Aristotle's Physics, where he referred to what came earlier and what will come later in respect to nature and cognition. Jessenius then, in purely Aristotelian terms (in the context of the discussion of the period), used the following distinction: "Since physics is closer to our cognition, it must be studied earlier. Metaphysics is then earlier from the perspective of nature, however, in temporal terms it follows later." ${ }^{20}$ Following the aforementioned distinction, Jessenius' predecessors and contemporaries elaborated on the methodology of science, however, Jessenius sees it only as one of the characteristics of metaphysics and physics. Jessenius does not focus on the issue of the method ${ }^{21}$ and he proceeds directly to more detailed reflections on the subjects of these different disciplines.

Physics, the aim of which is to analyse existence, defines its differences and achieves the definition of the genus, which serves as its object. Genera also represent the limit of the sphere of physics as an academic discipline, which is where metaphysics comes in, drawing from specifications on the level of genera but surpassing them to reach the transcendent Unity. ${ }^{22}$ The main goal of physics is to define the species. Things are defined by means of the specification of the nearest genus and specific difference as traditionally represented

20 Jessenius 1591a, c. 7, 4v.

21 Jessenius touches the issue of the method in his later speech delivered to Wittenberg students of medicine and philosophy in Jessenius 1600, see Nejeschleba 2007.

22 Jessenius 1591 a, c. 8, 5r. 
by the Porphyrian tree. Physics is not capable of moving towards more general definitions, transcending the generic term, and, accordingly, metaphysics cannot descend to dealing with specific terms. Metaphysics proves the principles of other sciences. ${ }^{23}$ This statement very clearly implies Jessenius' acceptance of Piccolomini's theories, since this is the point advocated by Piccolomini in order to refute Zabarella's separation of metaphysics and natural philosophy and the instrumentalist concept of scientific methodology.

\section{NICOLAS OF CUSA IN JESSENIUS' PADUA TREATISE?}

Let us delve further into the analysis of Jessenius' work. The differences between individual beings manifest themselves on the level of elements. The difference between fire, air, water and earth produces multiplicity, but Jessenius also emphasises the uniting impact of order the entirety of nature thus appears as "discordant in concord and concordant in discord, multiple in unity and one in multiplicity, unequal in equality and equal in inequality, diverse in sameness and identical in diversity." ${ }^{24}$

Pronouncements of this type are a rather surprising occurrence in the works of a follower of Aristotle and are more reminiscent of the Renaissance Platonic tradition beginning with Nicolas of Cusa and continuing in the works of Marsilio Ficino and Giovanni Pico della Mirandola, and then ending with

23 Jessenius 1591a, c. 8, 5r.

24 Jessenius 1591a, c. 4, 2 v.
Francesco Patrizi. ${ }^{25}$ This entire section concludes with the statement that everything which is common and serves as a principle to all other things, such as a unit (i.e. the principle of numbers) or fire (i.e. the principle of elements, which here refer to Heraclitus as mentioned in Aristotle's doxography) and of God as the principle of existence who, at the same time, serves as the foundation for general diversity. This ostentatious dialectic, proclaimed rather than thoroughly premeditated, shows that Jessenius was influenced by Platonism to a much greater extent than has been believed.

It may seem that Jessenius saw metaphysics as a science dealing with transcendental definitions (he himself used the term transcendentia). Jessenius viewed the term "transcendental" as a term that easily outstripped specification on the level of genera and which or the unity of which as highlighted by Jessenius - enabled one to interpret the "order of genera". ${ }^{26}$ Jessenius therefore once again advocated Piccolomini's concept of order and its relationship to metaphysics, although he did not further specify how this order of genera arises with reference to their transcendent unity, while previously seeing "general differences" as responsible for the constitution of order.

Jessenius' definition of metaphysics and its relationship with natural philoso-

25 Besides publishing an excerpt from Patrizi's Nova de universis philosophia, see Jessenius 1593, Jessenius later followed Renaissance Platonism, see Jessenius 1605 .

26 Jessenius 1591a, c. 8, 5r. 
phy has multiple facets. In Chapter XII of the treatise, he distinguished between physics and metaphysics and between the affirmative and negative science, as if referring to the Neoplatonist tradition of negative theology. Although the philosophy of Pseudo-Dionysius the Areopagite distinguishes between a positive and a negative path to knowledge, both are a method for acquiring knowledge of God, in the first case through naming and in the second case through denial since it is easier to determine what God is not than to determine what God is. Despite using similar terminology, Jessenius endowed the aforementioned terms with a more Aristotelian meaning. Affirmative physics, drawing on sensory perception, sees its subject in things, as they are in themselves (res in se ipsa), that is it explores the essence, habitus, form, and activity of things simply everything that may somehow be defined. On the contrary, metaphysics as a negative way, reflects on things outside itself (res extra se) and deals with privations, potentials, and matter. ${ }^{27}$ Jessenius presumably wanted to express that physics analyses "positive facts", while metaphysics turns its attention to "things" which, in terms of sensory perception, "do not exist". This, however, does not entitle metaphysics to pride itself in attributes such as infinite, absolute and universal - since it is a discipline that necessarily complements the finite and limited physics. Hence, metaphysics explores spiritual substances, causes, and the first principles of reason.
The analysis of Jessenius' treatise produced during his studies in Padua titled On Divine and Human Philosophy allows us to discuss the statements which are, to a certain extent, reminiscent of the philosophy of Nicolas of Cusa who stands at the onset of the Renaissance perhaps influencing all generations of Renaissance Platonists. The aforementioned "sameness in diversity and diversity in sameness", etc. may be complemented with other no less remarkable statements by Jessenius; these statements attract attention since their inclusion is rather surprising.

The points where Jessenius distinguishes between affirmative and negative metaphysics reveal Nicolas of $\mathrm{Cu}$ sa's somewhat "reshaped" idea about the coincidence of opposites (coincidentia oppositorum, in Jessenius' terms coincidentia differentiarum), but not as a characteristic of the deepest unity in God which can be seen in a spiritual vision, as in Cusanus' theories, but as a metaphysical methodology: “...physics observes the differences between things (as forms), whereas metaphysics reflects on their coincidence (as matters). Nevertheless, physics does not perceive things through differences as different, but as the same, and metaphysics does not see things in coincidence as coincidental but as different... this [metaphysics] grasps difference through coincidence, and [physics] sees coincidence in difference." ${ }^{28}$ Despite employing similar terminology, Jessenius again moved away from Cusanus' line of thinking, methodically employing the available dialectic

Jessenius 1591a, c. 12, 7v. 
to eventually describe a methodology of metaphysics based on coincidence as the understanding of differences. In this case, too, this shift relies on a strict adherence to Aristotle's ontology. Although Jessenius adopted the term "coincidence" used by Cusanus, it is set in a traditionally Aristotelian description of the relationship of mater and form. If it is true that physics is able to grasp the forms of things, then things are defined, or differentiated, by means of their forms which, at the same time, provide a general characteristic shared by things of the same kind as identical. Therefore, this differentiation is, in fact, a coincidence. Metaphysics that does not deal with specifications, but with negations - or indefinite matter - may see it as a coincidence of all things. On the other hand, matter is the principle of individuation while simultaneously being a principle giving rise to diversity. ${ }^{29}$ It seems that matter as a uniting principle in this case is ascribed a higher status than pure potentiality. This section, influenced by Cusanus' theories, thus concludes with an Aristotelian explication, however it is entirely obvious that Jessenius must have drawn on a source that incorporated Cusanus' legacy.

Cusanus' terminology appeared also in the concluding part of Jessenius' treatise, one entire chapter of which was dedicated to the "minimum" and the following to the "maximum". The dialectic of the minimum and the maximum was introduced by Nicolas of Cusa in his treatise On Learned Ignorance, in which he developed his theory on the coincidence of opposites. In Chapter IV of Book I, divine unity is characterised through the coincidence of the absolute maximum and the absolute minimum. God is seen as the maximum beyond which there can be nothing greater, encompassing everything that exists. And just as God surpasses everything in his greatness, there is also nothing which can be lesser, hence he is also the absolute minimum. For Cusanus, the dialectic of the maximum and the minimum while no contradiction can be attributed to the maximum thus coinciding with the minimum characterised as absolute simplicity - represents a sphere which transcends all terminological definitions. ${ }^{30}$ Cusanus further elaborates on this theory in his later works, specifically the works titled De coniecturis and De beryllo. He sees coincidence as a quality of the intellect as opposed to reason (ratio) which employs opposites. The coincidence of the maximum and the minimum thus becomes a model that allows one to better grasp the first principle. Both great and small things can be greater or lesser and that is why they are divisible. However, the maximum, being also the minimum, excludes any potential divisibility. Therefore, when searching for a simple indivisible maximum, attention must be turned to the examination of the minimum. From the minimum, grasped as a microcosm, the path leads further towards insight (as if through a beryl) into the construction of the universe, the macrocosm. The entire 1985, cf. Floss 2020. 
doctrine is then perceived by Cusanus as a reform of philosophy including a sharp critique of Aristotelian metaphysics and dualistic hylomorphism. ${ }^{31}$

Let us now focus on the concept of this minimum and maximum as presented in Jessenius' treatise. The minimum is characterised in a truly Cusanian way: it is Oneness in that it is indivisible and has no parts. While it is possible to distinguish between what is greater and what is lesser, minimums are all equal. Hence, minimums are identical for all things; there is no differentiation between them. A minimum is the primary principle of all things - Oneness - which gives rise to everything. In this way, all things are connected with their primal origin. Beings differ from each other based on their differences, however, their Oneness is identical and it enables them to be one with all other beings. ${ }^{32}$

Jessenius further reproduced the image of concentric circles employed by Cusanus. If we draw multiple circles around a single point, all of them share one centre on which they participate and in relation to which they are identical, although each circle is different. The minimum thus represents this common centre of all the circles. In addition, it is impossible to give this centre a name and it is free of all interpretation, since it is where all opposites, used both for assertions and for rejections, coincide (i.e. it is existing and non-existing), yet not in predicative terms but without differentiation in relation to these differences.

31 See Nicolas of Cusa 1988, 24-25, see Flasch 2001, pp. 37-38 and p. 101.

32 Jessenius 1591a, c. 12, 8r.
The minimum is thus considered by Jessenius to be the beginning and the goal of all existing things, the beginning of the "maximum". The minimum is existing and non-existing in potentiality, preceding actuality, and a negation of both since it is neither anything nor nothing. Jessenius therefore followed up on Cusanus' metaphysical concept, considering the minimum to be the very subject of metaphysics.

Nevertheless, Jessenius brought the dialectic of the minimum and the maximum to a different level than the one presented in Cusanus' theories. Most of all, he eliminated the theological context in which the entire doctrine originated and addressed the minimum and the maximum almost exclusively in the context of the relation between physics and metaphysics. While Nicolas of Cusa viewed God, the highest of beings situated above all opposites, as both the maximum and, thanks to the dialectic, the minimum, Jessenius made no explicit reference to God and reserved the term minimum to reflections on the first beginning and the principle of all existing and non-existing things. He did not identify the maximum as God, but saw it as the actuality of the minimum, which is, in fact, the maximum's potentiality. For Jessenius, the maximum is reduced to its second meaning attributed by $\mathrm{Cu}$ sanus, that is only the universe, which Cusanus called the limited or contracted maximum as opposed to God as the absolute maximum. It suffices to note that Jessenius did not mention Cusanus' specific term of contractio at all. Jessenius illustrated the relationship between the 
minimum and the maximum using the relationship between potentiality and actuality. A potentiality in the minimum becomes an actuality in the maximum. And this relation can be applied to human cognition: what is a potentiality in nature becomes an actuality in cognition; therefore, what is the maximum in cognition becomes a minimum in nature and vice versa. Jessenius used Cusanus' dialectic almost constantly without further expanding on the individual lists of potentialities and actualities, minimums and maximums, their successions and dependences.

Jessenius concludes: if conceiving the minimum as the subject of metaphysics, its actuality - the maximum - is then addressed in physics. Then he quickly came to distinguish two "spheres of knowing": the physical sphere (i.e. sensory perception which provide the grounds for physics) and the intellectual (i.e. the metaphysical sphere). Subsequently, in relation to the division between sensory perception and rational cognition, he provided the concluding characteristic of metaphysics and natural philosophy: physics proceeds from the effect to the cause whereas metaphysics moves from the cause to the effect. The difference between induction and deduction, however, is not discussed in further detail in Jessenius' book and so it will only be addressed in relation to his later work where the issue of methodology is mentioned. The chapters on the minimum and the maximum in Jessenius' treatise resemble Cusanus' theories, namely those included in Book I and II of On Learned Ignorance.
Jessenius revised Cusanus' theories for the purposes of his work. It was not his objective to further develop Cusanus' philosophy, but to promote Francesco Piccolomini's ideas about metaphysics and natural philosophy by means of the aforementioned dialectic, that is to point out the connection between these two disciplines and the superior position of metaphysics which defines the rules for physics. This purposeful inclusion of the "Cusanian" diversion appears to be a non-integral part of the treatise; it does not fit within the whole concept of the work. Jessenius did not dispute the legitimacy of his previous Aristotelian discourse and he apparently did not see any reason why his Cusanian exposé should affect the principles of Aristotelian philosophy. The coincidental dialectic thus did not result in any differentiation between the three levels of knowledge and the three powers of cognition, these being sensory perception, discursive reason, and intellect, which should have been able to see unity in the coincidence of opposites. Jessenius, on the contrary, sticks to the Aristotelian description of knowledge, which starts with sensory experience and ends with terminological analysis. Likewise, his treatise did not include Cusanus' critique of Aristotelian dualism of potentiality and actuality. Unlike Cusanus, who required a third principle which would combine both of the previous ones - connection (cone$x i o)$, Jessenius employed the relation between the two principles, possibility and implementation, and he used it as a manual on how to interpret the 
relationship between the minimum and the maximum, metaphysics and physics.

Still, the influence of Cusanus' philosophy on Jessenius' treatise is noteworthy for historical and philosophical reasons. It is clear that Cusanus' work was widespread in Italy in the $16^{\text {th }}$ century and that the fact that Giordano Bruno came across the text during his studies did not occur merely by chance. ${ }^{33}$ Moreover, Jessenius' treatise produced in Padua directly proves that the thinking of Nicolas of Cusa was well received not only outside the university (for example, in the works of French thinkers of the $16^{\text {th }}$ century or in the theories of Giordano Bruno who was a solitary figure standing outside all of the philosophical trends pursued at the university), but that $\mathrm{Cu}$ sanus' theories were partly discussed in academic circles. Regardless, there is not sufficient evidence to show that Cusanus' philosophy was studied by Jessenius' teacher, Francesco Piccolomini, whose theories might have served as Jessenius' inspiration.

Jessenius' disputation from the Padua period, which, according to Josef Král is not out of line with the traditional Aristotelian-Scholastic line of thinking, has, in the end, turned out to be a treatise defending the Platonised Aristotelianism of Francesco Piccolomini in his dispute with Jacopo Zabarella; furthermore, it even incorporates ideas from the philosophy of Nicolas of Cusa. 


\section{BIBLIOGRAPHY}

Baldini, A. E. (1980). "Per la biografia di Francesco Piccolomini". Rinascimento 20, pp. 389-420.

Claessens, G. (2012). "Francesco Piccolomini on Prime Matter and Extension". Vivarium 50(2), pp. 225-44.

Claessens, G. (2014). "A Sixteenth-Century Neoplatonic Synthesis: Francesco Piccolomini's theory of Mathematics and Imagination in the Academicae Contemplationes". The British Journal for the History of Science 47(3), pp. 421-31.

Cusa, Nicolas de. (1932). De docta ignorantia (eds. E. Hoffmann, \& R. Klibansky). Heidelberger Ausgabe der Opera omnia. Vol. I. Lipsiae: Felix Meiner.

Cusa, Nicolas de. (1988). De Beryllo (eds. H. G. Senger, \& K. Bormann). Nicolai de Cusa Opera Omnia. Vol. XI/1. Hamburg: Felix Meiner.

Flasch, K. (2001). Nicolaus Cusanus. München: C. H. Beck.

Flasch, K. (2002). "Cusano e gli intellettuali italiani del quattrocento". IN: C. Vasoli, \& C. Pissavino (eds.), Le filosofie del rinascimento, Milano: Bruno Mondadori, pp. 175-192.

Floss, P. (2020). The Philosophy of Nicholas of Cusa. An Introduction into His Thinking. Basel: Schwabe.

Garin, E. (2008). History of Italian Philosophy. Amsterdam / New York: Rodopi.
Hopkins, J. (1985). Nicholas of Cusa On Learned Ignorance : A Translation and an Appraisal of De Docta Ignorantia. 2nd ed. Minneapolis: A.J. Benning Press.

Jardine, N. (1997). "Keeping Order in the School of Padua: Jacopo Zabarella and Francesco Piccolomini on the Offices of Philosophy". IN: D. A. di Liscia \& E. Kessler, \& Ch. Methuen (eds.), Method and Order in Renaissance Philosophy of Nature: The Aristotle Commentary Tradition, Aldershot: Ashgate, pp. 183-209.

Jesenský, J. (2019). Proti tyranům (Pro vindiciis contra tyrannos). Ed. K. Šolcová. Praha: Academia.

Jessenius, Johannes. (1591a). De divina humanaque philosophia progymnasma peripateticum. Ad Divum Rudolphum II. Rom. Imperatorem, Ungariae et Boemiae Regem, Archiducem Austriae Etc. Venetiis: Apud Joachinum Bruinolum.

Jessenius, Johannes. (1591b). De putrescentis bilis in febre tertiana exquisita intermittente loco. Disputatio ad inclytum Vratisiaviensem senatum. Disputabitur publice Patavii in Templo S. Francisci. Die 8. Augusti hora 20. Patavii: Apud Petrum Marinellum.

Jessenius, Johannes. (1593). Zoroaster. Nova, brevis veraque de universo philosophia. Wittebergae: Crato.

Jessenius, Johannes. (1600). Et philosophiae et medicinae solidae studiosis. Witebergae: Typis M. Iohannis Cratonis. 
Jessenius, Johannes. (1605). De anima et corpore universi, AKROASIS PERIPATETIKE. Pragae: Typis Haeredum M. Danielis Adami a Veleslavina.

Kessler, E. (2007). “Intellective Soul”. IN: C. B. Schmitt, Q. Skinner \& E. Kessler, \& J. Kraye (Eds.), The Cambridge History of Renaissance Philosophy, Cambridge: Cambridge University Press, pp. 485-534.

Král, J. (1923). “Jessenius filozof”. Česká mysl 19, pp. 129-41, 211-22.

Kraye, J. (2002). "Eclectic Aristotelianism in the Moral Philosophy of Francesco Piccolomini”. IN: G. Piaia (ed.), La presenza dell'aristotelismo padovano nella filosofia della prima modernità, Roma - Padova: Antenore, pp. 57-82.

Lines, D. A. (2002). Aristotle's Ethics in the Italian Renaissance (ca. 1300-1650): the universities and the problem of moral education. Leiden: Brill.

Lines, D. A. (2015a). "Latin and Vernacular in Francesco Piccolomini's moral philosophy" IN: D. A. Lines, \& E. Refini (eds.), Aristotele fatto volgare": Tradizione aristotelica $e$ cultura volgare nel Rinascimento, Pisa: ETS, pp. 169-199.

Lines, D. A. (2015b). "Piccolomini, Francesco". IN: M. Sgarbi (ed.), Encyclopedia of Renaissance Philosophy, Cham: Springer.

Nejeschleba, T. (2007). “Johannes Jessenius's Conception of Method". Acta Comeniana 20-21(44-45), pp. 9-23.
Nejeschleba, T. (2008). Jan Jessenius v kontextu renesanční filosofie. Praha: Vyšehrad.

Nejeschleba, T. (2014). "Johannes Jessenius, Between Plagiarism and an Adequate Understanding of Patrizi's Philosophy”. IN: P. R. Blum, \& T. Nejeschleba (eds.), Francesco Patrizi. Philosopher of the Renaissance, Olomouc: UP Olomouc, pp. 359-69.

Nejeschleba, T. (2019). "Il rinascimento veneziano nell'Europa centrale: Aristotelismo e Platonismo nell'opera di Johannes Jessenius (1566-1621), laureato dell'Università di Padova”. IN: R. Bassi (ed.), Rinascimento veneto e rinascimento europeo / European and Venetian Renaissance, Pisa: Edizioni ETS, pp. 183-94.

Pick, F. (1926). Johannes Jessenius de Magna Jessen. Arzt und Rektor in Wittenberg und Prag hingerichtet am 21. Juni 1621. Ein Lebensbild aus der Zeit des Dreissigjährigen Krieges. Leipzig: Barth.

Plastina, S. (2002). “Concordia Discors: Aristotelismus und Platonismus in der Philosophie des Francesco Piccolomini”. IN: M. Mulsow (ed.), Das Ende des Hermetismus, Tübingen: Mohr Siebeck, pp. 211-34.

Savonarola, H. (1596). Universae Philosophiae Epitome. Wittebergae: typis Simonis Grenenbergii.

Schmitt, C. B. (1983). Aristotle and the Renaissance. Cambridge, Mass.: Harvard University Press. 
Šolcová, K. (2015). “Johannes Jessenius's Pro vindiciis contra tyrannos oratio and the Reception of Monarchomachy in the Bohemian Lands". Acta Comeniana 29(53), pp. 137-68.

Spruit, L. (1995). Species Intelligibilis: From Perception to Knowledge. Volume Two. Re- naissance Controversies, Later Scholasticism, and the Elimination of Intelligible Species in Modern Philosophy. Leiden / New York: Brill.

Várossová, E. (1987). "Prírodná filozofia Jána Jessenia”. IN: J. Bodnár (ed.), Dejiny filozofického myslenia na Slovensku I, Bratislava: Veda. 